\title{
Mage-b vaccine delivered by recombinant Listeria monocytogenes is highly effective against breast cancer metastases
}

\author{
SH Kim', F Castro', D Gonzalez', PC Maciag ${ }^{2,3}$, Y Paterson ${ }^{3}$ and C Gravekamp*,1,4 \\ 'California Pacific Medical Center Research Institute, 475 Brannan Street, Ste 220, San Francisco, CA 94 I07, USA; ${ }^{2}$ Advaxis Inc., 675 US Highway I, \\ North Brunswik, NJ 08902, USA; ${ }^{3}$ Department of Microbiology, University of Pennsylvania, 323 Johnson Pavilion, 36 th St and Hamilton Walk, \\ Philadelphia, PA 19104-6076, USA
}

New therapies are needed that target breast cancer metastases. In previous studies, we have shown that vaccination with pcDNA3. I Mage-b DNA vaccine is effective against breast cancer metastases. In the study presented here, we have further enhanced the efficacy of Mage-b vaccination through the improved delivery of the vaccine using recombinant Listeria monocytogenes (LM). Three overlapping fragments of Mage-b as well as the complete protein-encoding region of Mage-b have been expressed as a fusion protein with a truncated non-cytolytic form of listeriolysin $O(L L O)$ in recombinant LM. These different Mage-b vaccine strains were preventively tested for their efficacy against breast cancer metastases in a syngeneic mouse tumour model 4TI. The LM-LLO-Mageb/2nd, expressing position 31 I-660 of the cDNA of Mage-b, was the most effective vaccine strain against metastases in the 4TI mouse breast tumour model. Vaccination with LM-LLO-Mage-b/2nd dramatically reduced the number of metastases by $96 \%$ compared with the saline group and by $88 \%$ compared with the vector control group (LM-LLO), and this correlated with strong Mage-b-specific CD8 T-cell responses in the spleen, after restimulation with Mage-b. However, no effect of LM-LLO-Mage-b/2nd was observed on 4TI primary tumours, which may be the result of a complete absence of Mage-b-specific immune responses in the draining lymph nodes. Vaccination with LM-LLO-Mage-b/2nd could be an excellent follow-up after removal of the primary tumour, to eliminate metastases and residual tumour cells.

British Journal of Cancer (2008) 99, 74I -749. doi:I0.1038/sj.bjc.6604526 www.bjcancer.com

Published online 19 August 2008

(C) 2008 Cancer Research UK

Keywords: Mage-b DNA vaccine; Listeria monocytogenes; breast cancer metastases; 4TI model

Breast cancer is the most common cancer among women around the world (Althuis et al, 2005), and $40 \%$ of the women diagnosed with breast cancer will progress to metastatic disease (Berkowitz et al, 2000). Current treatment options for localised breast cancer include surgical resection of the primary tumour, assessment of the regional lymph nodes (LNs), and removal if positive, followed by adjuvant chemotherapy or hormonal therapy (Scart et al, 2002). Although first-line endocrine therapy with tamoxifen or the newer third generation aromatases is promising (Kurtz and Dufour, 2002), the cure rate of metastatic breast cancer is low (Alberg and Singh, 2001). Despite aggressive treatment, for most patients the elimination of metastases or residual tumour cells after surgery is incomplete, due to chemoresistance (Pardal et al, 2003). Thus, metastases and not the primary tumour is the most important contributor to breast cancer morbidity and mortality. Treatments that specifically reduce or eliminate distant metastases or residual tumour cells should therefore be the focus of our efforts, and will offer the greatest promise in improving the outcome for patients with metastatic breast cancer. Enhancement of specific helper and

\footnotetext{
*Correspondence: Professor C Gravekamp;

E-mail: cgraveka@aecom.yu.edu

${ }^{4}$ Current address: Albert Einstein College of Medicine, Department of Microbiology and Immunology, 1300 Morris Park Avenue, Forchheimer Bldg, Room 407A, Bronx, NY 1046I, USA

Received I4 April 2008; revised 26 June 2008; accepted 30 June 2008; published online 19 August 2008
}

cytotoxic T-lymphocyte (CTL) responses to breast tumours through vaccination with tumour-associated antigens (TAAs) could potentially lead to the specific elimination of micrometastases and/or residual tumour cells.

So far, many TAA have been identified in human tumours of various histological origins. The MAGE antigens are particularly interesting for the development of breast cancer vaccines, because their expression (MAGE-A and/or MAGE-B) has been frequently detected in human breast tumour biopsies (92\%) (Park et al, 2002), but not in normal tissues (De Backer et al, 1995; De Plaen et al, 1999). Various clinical trials have shown that vaccination with MAGE-1 and -3 peptides or protein, in patients with melanoma was effective against metastases (Thurner et al, 1999; Marchand et al, 2003; Kruit et al, 2005; Lurquin et al, 2005; Van Baren et al, 2005). These human clinical trials not only show the potential of MAGE vaccination against metastases but also the need to further optimise the efficacy of MAGE-based vaccines to improve the clinical outcome. Such optimisations are ideally carried out in the mouse.

In previous studies, we demonstrated that DNA vaccination with mouse Mage-b in metastatic mouse breast tumour models $4 \mathrm{TO} 7 \mathrm{cg}$ and $4 \mathrm{~T} 1$, highly expressing Mage-b, reduced the number of metastases significantly, although not completely (Sypniewska et al, 2005; Gravekamp, 2007; Gravekamp et al, 2008). In the study presented here, we further enhanced the efficacy of Mage-b vaccine through improved delivery of the vaccine using recombinant Listeria monocytogenes (LM). Listeria monocytogenes is an intracellular pathogen that primarily infects antigen-presenting 
cells (APCs) such as macrophages and dendritic cells (DCs; for review see Paterson and Maciag, 2005). Listeria monocytogenes is an attractive vaccine vector, because proteins produced by this bacterium can be presented as short peptides through both the MHC class I and II pathways generating both CD4 and CD8 T-cell responses to these antigens (Hsieh et al, 1993). Direct killing of tumour cells occurs through the function of CD8 T cells, but the killing may be enhanced through the activation of CD4 $\mathrm{T}$ cells (Hsieh et al, 1993). It has been shown that vaccine antigens delivered through LM are effective against primary tumours in animal models (Pan et al, 1999; Gunn et al, 2001; Singh et al, 2005). As discussed earlier, metastases, and not the primary tumour, contributes most to breast cancer morbidity and mortality. In this study, we demonstrate a dramatic effect of Mage-b vaccination delivered through LM on metastases in a highly metastatic breast tumour model $4 \mathrm{~T} 1$.

\section{MATERIALS AND METHODS}

\section{Mice}

Normal female Balb/c mice (3-month old) were obtained from Simsonsen (San Francisco, CA, USA) and maintained in the animal husbandry facility of the Pacific Medical Center Research Institute (CPMCRI) according to the Association and Accreditation of Laboratory Animal Care (AACAC) guidelines.

\section{Plasmids and Listeria monocytogenes}

pcDNA3.1-Mage-b/V5 was developed in our laboratory (Sypniewska et al, 2005). Mouse GM-CSF plasmid (CMV1-GM-CSF) was kindly provided by Dr Stephen Johnston (the Center for Innovations in Medicine, the Biodesign Institute at Arizona State University) (Chambers and Johnston, 2003). The listerial pGG-34 plasmid, expressing the positive regulatory factor A (prfA), was developed in the laboratory of Yvonne Paterson, University of Pennsylvania, PA, USA (Singh et al, 2005). The prfA-negative strain XFL-7 of LM (Gunn et al, 2001) has been used in this study.

\section{Cells and cell culture}

The $4 \mathrm{~T} 1$ cell line was derived from a spontaneous mammary carcinoma in a BALB/c mouse (Aslakson and Miller, 1992). Various $4 \mathrm{~T} 1$ sublines have been generated with different patterns of metastases (Lelekakis et al, 1999). The 4T1 cell line used in this study is highly aggressive, metastasizing predominantly to the mesenteric LNs (MLNs), and less frequently to the diaphragm, portal liver, spleen, and kidneys (Gravekamp et al, 2008). The 64pT mouse mammary tumour cell line is a spontaneous fusion between mammary cell lines $4 \mathrm{TO} 7$ and $68 \mathrm{H}$ and is non-metastatic (Rak et al, 1992). Both 4T1 and 64pT were kindly provided by Dr Fred Miller (Karmanos Cancer Institute, Detroit, MI, USA). Both cell lines were grown in Dulbecco's Modified Eagle's Medium (DMEM) supplemented with $10 \%$ foetal bovine serum (FBS), $1 \mathrm{~mm}$ mixed non-essential amino acids, $2 \mathrm{~mm} \mathrm{~L}$-glutamine, insulin (0.5 HSP units per ml) penicillin $\left(100 \mathrm{U} \mathrm{ml}^{-1}\right)$ and streptomycin $\left(100 \mu \mathrm{g} \mathrm{ml}^{-1}\right)$

\section{Breast tumours and metastases}

Breast tumours and metastases were generated in BALB/c mice by the injection of $10^{5}$ cells of the mouse mammary tumour cell line $4 \mathrm{~T} 1$, into a mammary fat pad as described previously (Gravekamp et al, 2008). Primary tumours were detected by palpation within 1-2 weeks in live mice. To determine the tumour size in situ, the perpendicular largest diameters of the tumour were measured with a caliper. Fourteen days after injection of the tumour cell line, the mice were euthanized, weighed, and necropsied to evaluate the presence and frequency of metastases and to determine the weight and size of primary tumours. Primary tumours extended to the chest cavity lining, and predominantly metastasized to the MLNs $(81 \%)$, and less frequently to the diaphragm $(7 \%)$ and portal liver $(4 \%)$, as well as to the surface of spleen (4\%) and kidneys (4\%). Metastases were visible to the naked eye as nodules. The total number of metastases per mouse (MLN, diaphragm, liver, kidney, and spleen) was determined. Normal and tumour tissues were collected aseptically and kept at $-80^{\circ} \mathrm{C}$, or fixed in $10 \%$ Zinc solution for $48 \mathrm{~h}$ and kept in $70 \%$ ethanol, until use. The primary tumours and metastases were confirmed by histology or RT - PCR. In some cases, the metastases were too small for histological analysis, and only RT - PCR for the detection of Mage-b expression (not expressed in normal cells) was performed. Normal cells do not express Mage-b.

\section{Construction and characterisation of LM-based Mage-b vaccine strains}

Three overlapping fragments as well as the complete proteinencoding region of Mage-b were cloned in the prfA-positive plasmid pGG-34 (Gunn et al, 2001) under the control of a hemolysin promoter $(\mathrm{P} h l y)$, and as fusion protein with a truncated non-cytolytic form of listeriolysin O (LLO). The first fragment located at the $\mathrm{N}$-terminal site is $349 \mathrm{bp}$ (position 3-352), the second fragment adjacent to the first fragment is also $349 \mathrm{bp}$ (position 311-660), and the third fragment at the C-terminal site is $379 \mathrm{bp}$ (position 610-990). The Mage-b fragments were obtained by PCR from plasmid pcDNA3.1-Mage-b/V5, generated in a previous study (Sypniewska et al, 2005). For each construct, a restriction site Xho1 (underlined) was included in the forward primer, and a myc Tag (bold), followed by a stop codon and restriction site XmaI (underlined) in the reverse primer. The following primers were designed to generate the first fragmant of Mage-b $\mathrm{F}^{1 \mathrm{st}} / 5^{\prime}$ : CTCGAGCCTAGGGGTCAAAAGAGTAAG and $\mathrm{R}^{1 \text { st }} / 5^{\prime}$ :CCCGGGTTATAGATCTTCTTCTGAAATTAGTTTTTGTTCA AACTTATCTAGCAGGAATTC; for the second fragment of Mage-b $\mathrm{F}^{\text {2nd }} / 5^{\prime}$ : CTCGAGAGGAAGGCTA GTGTGCTGATA and R2nd/5': CCCGGGTTATAGATCTTCTTCTG AAATTAGTTTTTGTT CTCCATGCAGAAATTGCCAGAC were designed; and for the third fragment of Mage-b $\mathrm{F}^{3 \mathrm{rd}} / 5^{\prime}$ : CTCGAGAACCGTGCCACTGAGCAAG $\mathrm{AG}$ and $\mathrm{R}^{3 \mathrm{rd}} / 5^{\prime}$ : CCCGGGTTATAGATCTTCTTCTGAAATTAGT TTTTGTTCCATGTTAGAGGACTTTTGGGA were designed. The Mage- $b$ fragments or complete Mage- $b$ were cloned into the listerial pGG-34 plasmid by digestion of the PCR products of Mage-b as well as the pGG-34 plasmid with XHoI and SmaI, followed by purification of the digests and ligation of pGG-34 with Mage using T4 DNA polymerase (Invitrogen, Life Technologies) and transformed into Escherichia coli. Positive colonies were analysed by restriction digestion with $\mathrm{XHoI}$ and $\mathrm{SmaI}$, and DNA sequencing. Subsequently, the plasmids of positive colonies were transformed into the recombinant prFA-negative LM strain XFL-7 (Hsieh et al, 1993) and analysed for the secretion of the Mage proteins by western blotting as described below. The LM-LLO used in this study is attenuated, that is, the coding region for the C-terminal part of the LLO (cytolytic domain that binds cholesterol in the membranes) protein has been deleted, and mutations have been introduced into the prfA gene (expressed by the pGG34 vector), which reduced the pathogenicity of the LM (Singh et al, 2005).

\section{Western blotting}

The Mage-b LM-based vaccines were grown overnight in LuriaBertani medium with $50 \mu \mathrm{g} \mathrm{ml}^{-1}$ of chloroamphenicol at $37^{\circ} \mathrm{C}$. Supernatants were precipitated with trichloro acetic acid (TCA) and resuspended in SDS sample buffer (Invitrogen, Life Technologies). Twenty microliters of each sample was loaded on a $4-12 \%$ 
Bis-Tris SDS-PAGE gel (Invitrogen, Life Technologies). The proteins were then transferred to a nitrocellulose membrane and probed with a rabbit polyclonal antiserum raised to the first 30 residues of the LLO protein (anti-proline, glutamic acid, serine, and threonine (PEST) (Pan et al, 1999). The secondary antibody $\mathrm{Ab})$ was an $\mathrm{HRP}$-conjugated anti-rabbit $\mathrm{Ab}$ (Pharmingen). In addition, transferred proteins were probed with mouse anti-myc Abs, followed by a goat antimouse IgG conjugated with HRP as secondary $\mathrm{Ab}$.

\section{RT-PCR and southern blotting}

RNA was isolated using Trizol according to the manufacturer's instructions (Life Technologies, Carlsbad, CA, USA). Conversion of $1 \mu \mathrm{g}$ of mRNA into cDNA was performed with Superscript Preamplification system (Life Technologies). Subsequently, $10 \mu \mathrm{l}$ of the cDNA was amplified by hot start PCR (Platinum PCR SuperMix, Life Technologies; 40 cycles at $94^{\circ} \mathrm{C}$ for $30 \mathrm{~s}, 58^{\circ} \mathrm{C}$ for $30 \mathrm{~s}, 72^{\circ} \mathrm{C}$ for $2 \mathrm{~min}$ ) in a thermocycler from Perkin-Elmer (Norwalk, CT, USA). To detect the expression of all three genes, that is, Mage- $b 1,-b 2$, or $-b 3$, we used the set of primers F111 $5^{\prime}-\mathrm{G}$ AGCTTGATCCACGAGTTC-3' and R769: 5'-AGGAGACCTGTCC TAGGC- $3^{\prime}$ published by De Backer et al (1995). The forward primer is located in the second exon and the reverse primer in the third exon of Mage- $b 2$, amplifying a $658 \mathrm{bp}$ fragment. $\beta$-actin was used as an internal control for RNA quality. Primers for $\beta$-actin were $5^{\prime}$-TCATGAAGTGTGACGTTGACATCCGT-3', and $5^{\prime}$-CCTA GAAGCATTTGCGGTGCACGATG-3' (Life Technologies). RT PCR products were separated in an ethidium-bromide-stained agarose gel, and transferred to an immobilon- $\mathrm{N}^{+}$membrane (Amersham, Buckinghamshire, England) and hybridised with a chemiluminescence-labelled and sequenced 993 bp Mage-specific probe (AY196960) according to the manufacturer's instructions (enhanced chemiluminescence; Amersham).

\section{Immunisation and tumour challenge}

The $\mathrm{LD}_{50}$ of each Mage-b vaccine strain was determined by vaccinating five mice with various doses of each vaccine strain $\left(10^{5}, 10^{6}, 10^{7}, 10^{8}\right.$ colony-forming units (CFU) $)$ in $500 \mu \mathrm{l}$ saline. The $\mathrm{LD}_{50}$ for all constructs was $10^{8} \mathrm{CFU}$.

To determine the efficacy of each Mage-b vaccine strain, Balb/C mice were immunised intraperitoneally (three times; 1 week time interval) with $0.1 \times \mathrm{LD}_{50}$ of each construct separately or combined (LM-LLO-Mage-b/1st, LM-LLO-Mage-b/2nd, LM-LLO-Mage-b/3d, LM-LLO-Mage-b/complete), or with $0.1 \times \mathrm{LD}_{50}$ of the control vector (LM-LLO), or with saline. For tumour induction, mice were injected with $10^{5} 4 \mathrm{~T} 1$ tumour cells into a mammary fat pad 4 days after the second immunisation. Fourteen days after tumour challenge, the mice were euthanized and analysed for tumour size, frequency, and location of metastases. A schematic view of the immunisations and tumour challenge is given in Figure 1.

\section{In vitro analysis of Mage-b-specific immune responses}

Cells from draining (inguinal) LNs and spleens were isolated according to standard protocols (Reeves and Reeves, 2003) from $\mathrm{BALB} / \mathrm{c}$ mice with or without $4 \mathrm{~T} 1$ tumours, that were immunised three times with $0.1 \times \mathrm{LD}_{50}$ of the vaccine (LM-LLO-Mage-b/2nd), or with $0.1 \times \mathrm{LD}_{50}$ the control vector (LM-LLO), or saline. Within each group, the spleen cells were pooled. Briefly, $2 \times 10^{5}$ cells from spleens or LNs were restimulated with $5 \times 10^{4}$ bone marrow (BM) cells (transfected with pcDNA3.1-Mage-b plasmid DNA and pCMV-GM-CSF plasmid DNA $(1 \mu \mathrm{g}$ of each plasmid DNA per $5 \times 10^{6}$ BM cells), using the Nucleofector kit of AMAXA (Gaithersburg, MD, USA), and cultured in $200 \mu \mathrm{l}$ of RPMI containing $10 \%$ FBS. Two days later, the frequency of IFN $\gamma$ - and

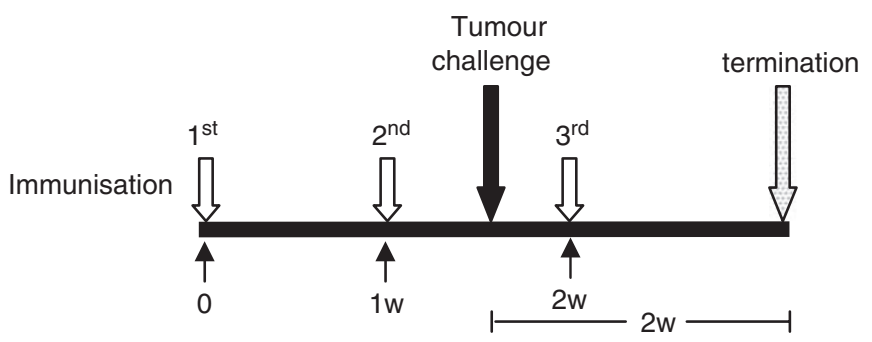

Figure I Schematic view of immunisations and tumour challenge. BALB/C mice were immunised three times intraperitoneally with $0.1 \times L D_{50}$ of each Listeria-based Mage-b vaccine strain or with the vector control strain LM-LLO, or saline, with I-week time intervals. Four days after the second immunization, mice were injected with $10^{5}$ 4TI tumour cells in a mammary fat pad. Two weeks after tumour challenge, mice were euthanized and analysed.

interleukin (IL)-2-producing cells was determined by ELISPOT according to the standard protocols (Pharmingen, San Diego, CA, USA). Positive cells were counted by an ELISPOT reader (CTL Immunospot $\mathrm{S} 4$ analyzer, Cellular Technology Ltd, Cleveland, $\mathrm{OH}$, USA). Spleen cells were depleted for CD8 T cells, using magnetic bead depletion techniques according to the manufacturer's instructions (Miltenyi Biotec Inc., Auburn, CA, USA). Fluorescence-activated cell sorting analysis showed that $\geqslant 90 \%$ of all CD8 $\mathrm{T}$ cells were removed after depletion (data not shown).

\section{The effect of IL-6 on Mage-b-specific immune responses}

To test the effect of IL- 6 on Mage-b-specific immune responses in vitro, purified IL-6 $\left(100 \mathrm{pg} \mathrm{ml}^{-1}\right)$ was added or not to the wells with spleen cells $\left(2 \times 10^{5}\right)$ and BM cells expressing Mage-b $\left(5 \times 10^{4}\right)$ in $200 \mu \mathrm{l}$ of RPMI containing $10 \%$ FBS. Two days later, the number of IFN $\gamma$-producing cells was determined by ELISPOT reader as described above. In addition, anti-IL-6 antibodies $\left(50 \mu \mathrm{g} \mathrm{ml}^{-1}\right)$ were either or not added to the wells with LNs $\left(2 \times 10^{5}\right)$ and syngeneic $64 \mathrm{pT}$ tumour cells $\left(1 \times 10^{4}\right.$; treated with mitomycin C; expressing highly Mage-b; Gravekamp et al, 2004), and secreting highly IL-6 (3000 $\left.\mathrm{pg} \mathrm{ml}^{-1}\right)$ (Gravekamp et al, 2008), in $200 \mu \mathrm{l}$ of RPMI containing $10 \%$ FBS. Two days later, the production of IFN $\gamma$ was determined by quantitative ELISA as described previously (Sypniewska et al, 2005). Anti-IL-6 antibodies and purified IL-6 were purchased from Pharmingen.

\section{RESULTS}

\section{Generation of the LM strains that secrete Mage-b}

Three recombinant LM strains that express and secrete overlapping fragments of Mage- $b$, as well as the complete proteinencoding region of Mage- $b$ have been designed and constructed (Figure 2A). These fragments of Mage-b were selected as alternative antigens for the following reasons: (1) to lose function of Mage-b (complete Mage-b may induce the growth of tumour cells (Yang et al, 2007), (2) smaller fragments are easier to secrete than larger fragments, and (3) to select the fragment with the most protective effect in vivo. All fragments have been cloned into the listerial pGG-34 expression vector as fusion protein with LLO. Listeriolysin $\mathrm{O}$ was used for its ability to improve the immunogenicity of poor immunogenic self-antigens (Singh et al, 2005). The secretion of Mage-b protein of each fragment, as well as the complete protein-encoding region of Mage-b has been confirmed by western blotting of the secreted listerial proteins (Figure 2B). The secreted fusion proteins LM-LLO/Mage-b/1st, 2nd, and 3rd are $61 \mathrm{kDa}$, whereas the 
A

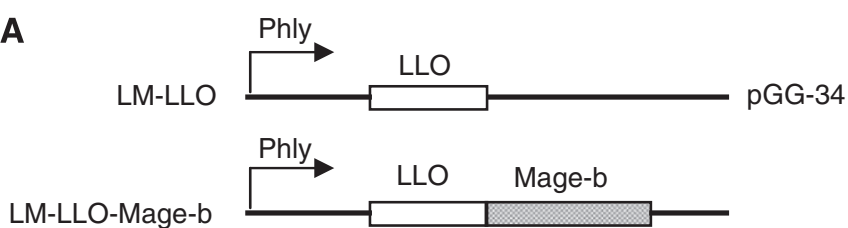

Mage-b

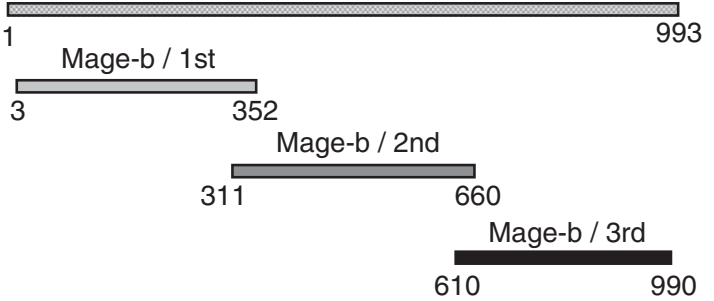

B

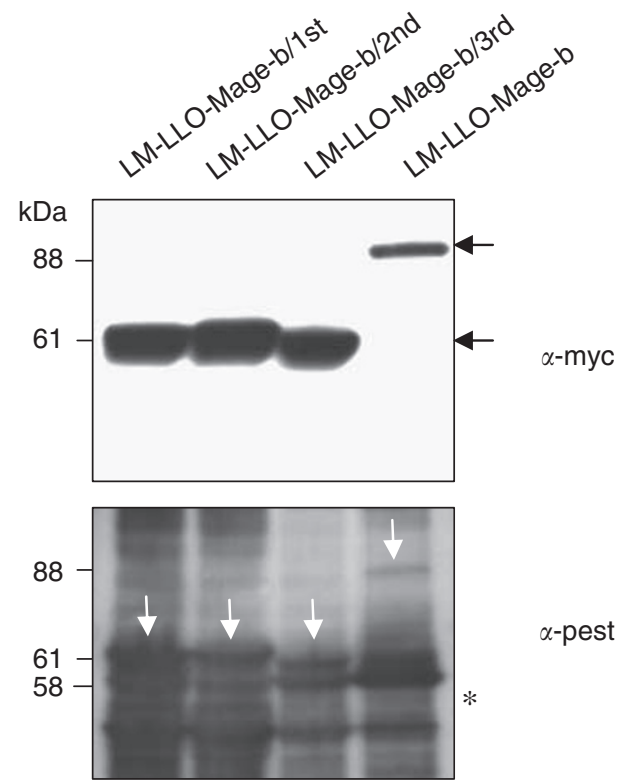

Figure 2 Construction and characterisation of Listeria-based Mage-b vaccine strains. (A) Three overlapping fragments of mouse Mage-b (homologous to human MAGE-B) were cloned as a fusion protein with a truncated non-cytolytic listeriolysin $\mathrm{O}(\mathrm{LLO})$ in the pGG-34 vector under the control of the listerial hemolysin promoter (Phly). (B) Secretion of LLO-Mage-b proteins by the Listeria-based vaccine strains was detected by western blotting using $\alpha$-myc antibodies (top) and $\alpha$-pest antibodies (bottom). In the western blot with $\alpha$-myc antibodies, the LLO-Mage-b proteins are indicated by black arrows, and in the western blot with $\alpha$-pest antibodies by white arrows. The complete Mage-b protein fused with truncated LLO represents a band of $88 \mathrm{kDa}$, whereas the three fragments of Mage-b fused with truncated LLO represent a band of $61 \mathrm{kDa}$. Endogenous LLO $(58 \mathrm{KDa})$ secreted by all LM is indicated by a star.

LM-LLO-Mage-b/complete is $88 \mathrm{kDA}$. It is clear from Figure $2 \mathrm{~B}$ that the Mage-b fragments were more efficiently secreted than the complete Mage-b.

\section{Mage-b transcripts in 4T1 primary tumours and metastases}

To confirm the expression of Mage-b in the $4 \mathrm{~T} 1$ primary tumours and metastases (MLNs, diaphragm, portal liver, spleen, and kidneys), we randomly analysed tissue samples from primary tumours and metastases by RT-PCR and southern blotting

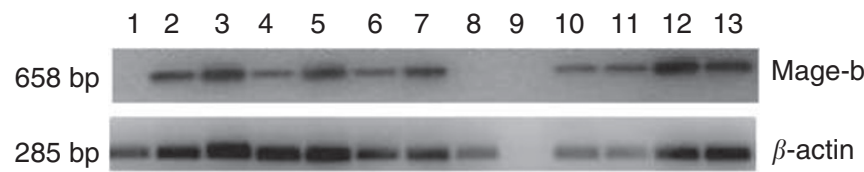

Figure 3 Expression of Mage-b in 4TI primary tumours and metastases The Mage-b-specific RT-PCR product of $632 \mathrm{bp}$ was detected by southern blotting using DNA probe encoding Mage-b. $\beta$-actin (285 bp) was used to determine RNA quality. The lanes were loaded as follows: lane I: normal breast tissue; lane 2: 4TI tumour; lane 3: 4TI tumour, lane 4: metastasis in peritoneal cavity (PC); lane 5: metastasis in PC; lane 6: metastasis liver; lane 7: metastasis liver; lane 8: metastasis spleen; lane 9: metastasis spleen; lane 10: metastasis kidney; lane 11: metastasis kidney; lane 12: metastasis diaphragm; lane 13: metastasis diaphragm.

(Figure 3). All primary tumours and metastases, except two metastases present on the surface of the spleen, did express Mage-b. From one metastasis, the quality of the mRNA was poor, as indicated by the absence of $\beta$-actin transcription products. The other metastasis may have lost Mage-b expression.

\section{Preventive effect of vaccination with the various LM-based Mage-b vaccine strains}

The preventive effect of each LM-based Mage-b vaccine strain on metastases and primary tumours has been determined in the $4 \mathrm{~T} 1$ model. Mice were immunised with the vaccine strains and challenged with 4T1 tumour cells as outlined in Figure 1. It appeared that LM-LLO-Mage-b/2nd was the most effective vaccine strain (Figure 4A). LM-LLO-Mage-b/2nd vaccination significantly reduced the number of metastases by $96 \%$ compared with the saline group and by $92 \%$ compared with the vector control group (LM-LLO). The average number of metastases as determined for each group was 9 (LM-LLO-Mage-b/2nd), 104 (LM-LLO), and 199 (saline). However, none of the Mage-b vaccine strains reduced the growth of the primary tumours (Figure 4B). Moreover, the LM strain expressing the complete Mage-b enhanced the tumour growth by more than two times compared with the saline group (Mann-Whitney, $P=0.0005)$. Therefore, LM-LLO-Mage-b complete was excluded from further vaccine studies. In previous studies, we have shown that complete Mage-b is able to enhance tumour growth (Yang et al, 2007). Our results suggest that LMLLO-Mage-b may have a direct effect on the tumour cells. This idea is currently under investigation.

In summary, LM-LLO-Mage-b/2nd was the most effective strain and therefore selected for further analysis. Vaccine studies with LM-LLO-Mage-b/2nd were repeated to confirm its dramatic effect on the metastases, and to analyse Mage-b-specific immune responses in vitro.

Vaccinations with LM-LLO-Mage-b/2nd were repeated three times in the 4T1 model. Immunization with LM-LLO-Mage-b/2nd significantly reduced the number of metastases by $96 \%$ compared with the saline group and by $88 \%$ compared with the vector control group (LM-LLO; Figure 4C). The average number of metastases per group as determined was 7 (LM-LLO-Mage-b/2nd), 59 (LM-LLO), and 158 (saline). Again, while the effect was dramatic on the metastases, no effect of LM-LLO-Mage-b/2nd was observed on the primary tumour (Figure 4D).

Pure preventive immunizations, that is, three immunisations followed by tumour challenge, 10 days after the last immunisation, resulted also in a significant reduction in the number of metastases in the mice immunised with LM-LLO-Mage-b/2nd compared with the saline group (Mann-Whitney, $P=0.0159)$ but not compared with the control vector group (data not shown). Moreover, two immunisations before and one after tumour challenge were more effective than three preventive immunisations. 
A Mann-Whitney test

Saline vs LM-LLO-Mage-b/1st

Saline vs LM-LLO-Mage-b/2nd

Saline vs LM-LLO-Mage-b/3rd

Saline vs LM-LLO-Mage-b/complete

Saline vs LM-LLO-Mage-b/1st+2nd

Saline vs LM-LLO-Mage-b/2nd+3rd

Saline vs LM-LLO-Mage-b/1st+3rd

Saline vs LM-LLO-Mage-b/1st+2nd+3rd

Mann-Whitney test

LM-LLO vs LM-LLO-Mage-b/1st

LM-LLO vs LM-LLO-Mage-b/2nd

LM-LLO vs LM-LLO-Mage-b/3rd

LM-LLO vs LM-LLO-Mage-b/complete

LM-LLO vs LM-LLO-Mage-b/1st+2nd

LM-LLO vs LM-LLO-Mage-b/2nd+3rd

LM-LLO vs LM-LLO-Mage-b/1st+3rd

LM-LLO vs LM-LLO-Mage-b/1st+2nd+3rd

B
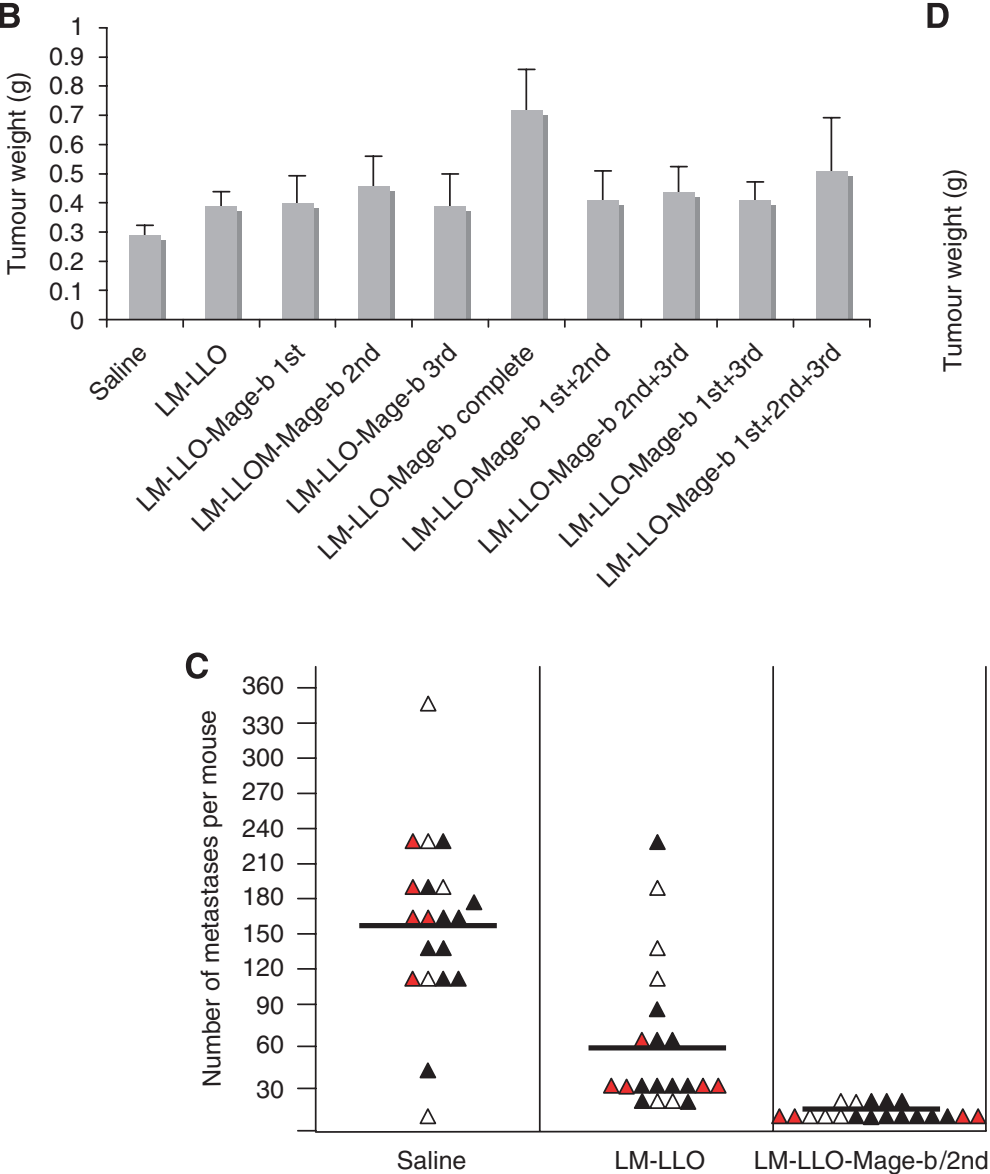

$P=0.0526$

$P=0.0184$

$P=0.0526$

$P=0.0291$

$P=0.0447$

$P=0.0655$

$P=0.0526$

$P=0.0800$

$P=0.0983$

$P=0.0114$

$P=0.0806$

$P=0.0325$

$P=0.0887$

$P=0.0806$

$P=0.0736$

$P=0.0800$
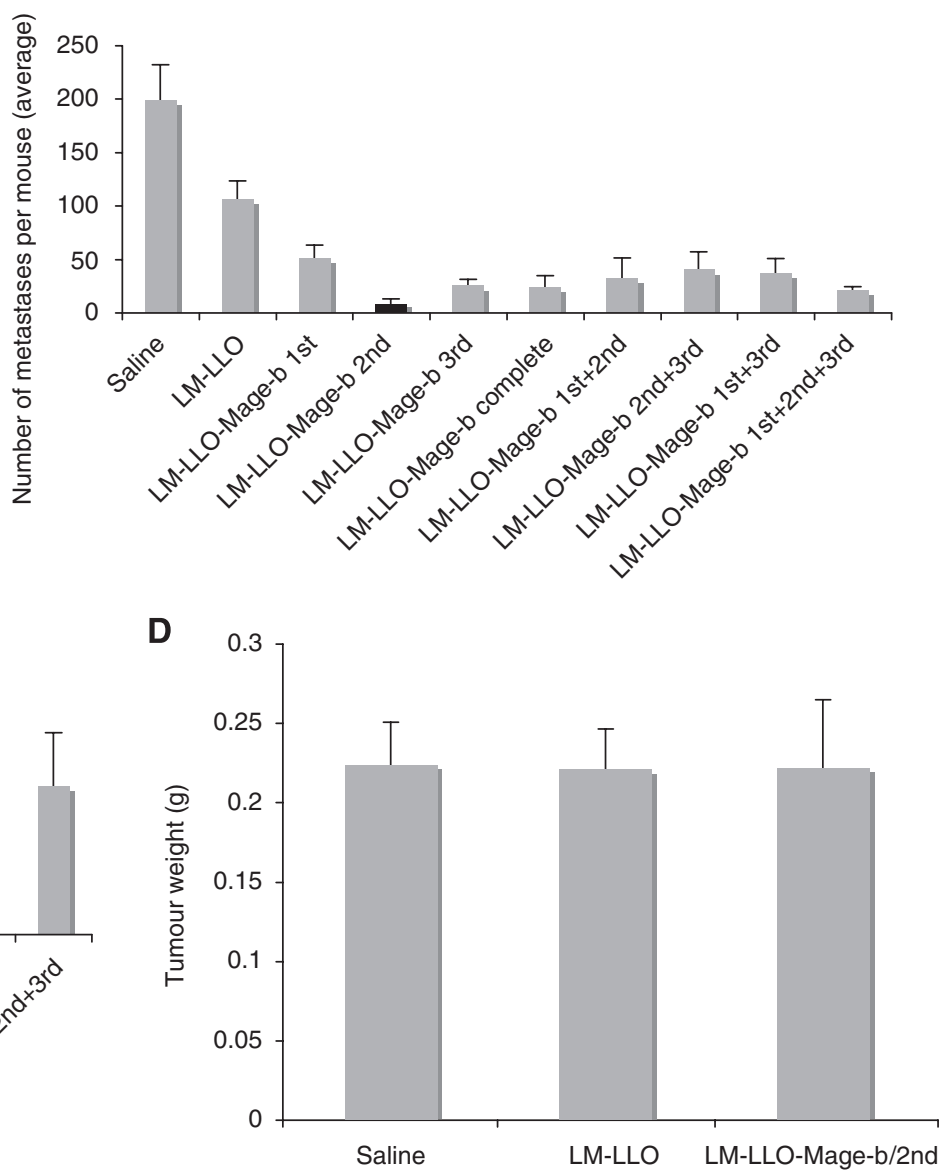

Mann-Whitney test

LM-LLO-Mage-b/2nd vs Saline $P<0.0001$

LM-LLO-Mage-b/2nd vs LM-LLO $P<0.0001$

$\triangle$ Experiment 1

A Experiment 2

$\triangle$ Experiment 3

Figure 4 Strong effect of vaccination with LM-LLO-Mage-b/2nd on metastases but not on primary tumours in the 4TI model. BALB/c mice were immunised with the various Listeria-based Mage-b vaccine strains and challenged with 4TI tumour cells as outlined in Figure I. Two weeks after tumour challenge, mice were euthanized and the number of metastases $(\mathbf{A})$ and tumour size $(\mathbf{B})$ was determined per mouse. LM-LLO-Mage-b/2nd was the most effective vaccine strain against 4TI metastases, whereas none of the Listeria-based Mage-b vaccines had any inhibitory effect on tumour growth. These vaccine studies were repeated three times in independent experiments with the most effective vaccine strain, that is, the LM-LLO-Mage-b/2nd. Again, the number of metastases $(\mathbf{C})$ and tumour size $(\mathbf{D})$ was determined per mouse. Results were averaged and subjected to statistical analysis using Mann-Whitney test ( $n=5$ mice per group in each experiment). The error bars represent the s.e.m. In panel C, each triangle represents the number of metastases per mouse, and the vertical bars represent the average number of metastases per mouse.

\section{Mage-b-specific immune responses in vitro}

Mage-b-specific immune responses were analysed in spleen and LNs of vaccinated and control mice. First, vaccinated and control mice without $4 \mathrm{~T} 1$ tumours and metastases were analysed for Mageb-specific immune responses. A significant increase was observed in the number of IFN $\gamma$-producing cells in the group of LM-LLOMage-b/2nd compared with the control groups, demonstrating the high immunogenicity of Mage-b/2nd (Figure 5A). Second, vaccinated and control mice bearing $4 \mathrm{~T} 1$ tumours and metastases were analysed for Mage-b-specific immune responses. A significant increase in the number of IFN $\gamma$-producing cells was observed 
A

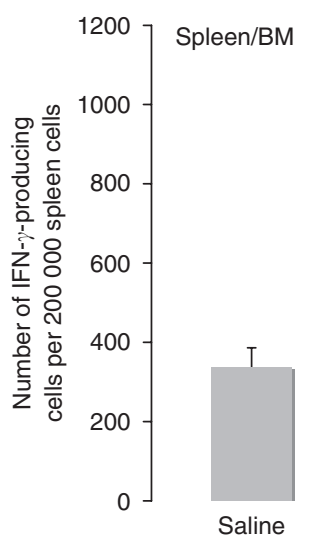

Mice without tumours

Mann-Whitney test

LM-LLO-Mage-b/2nd vs Saline $P=0.0087$

LM-LLO-Mage-b/2nd vs LM-LLO $P=0.0260$

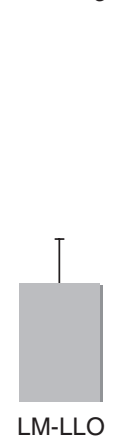

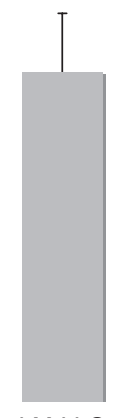

LM-LLO-

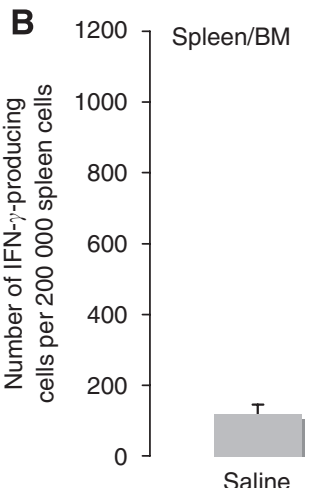

Mann-Whitney test

LM-LLO-Mage-b/2nd vs Saline $P<0.0001$

LM-LLO-Mage-b/2nd vs LM-LLO $P<0.0001$

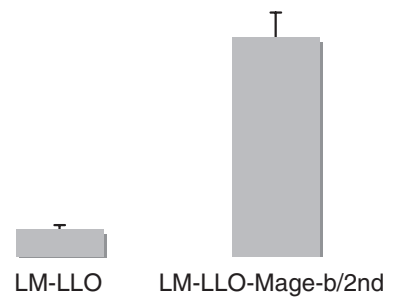

Mice with tumours
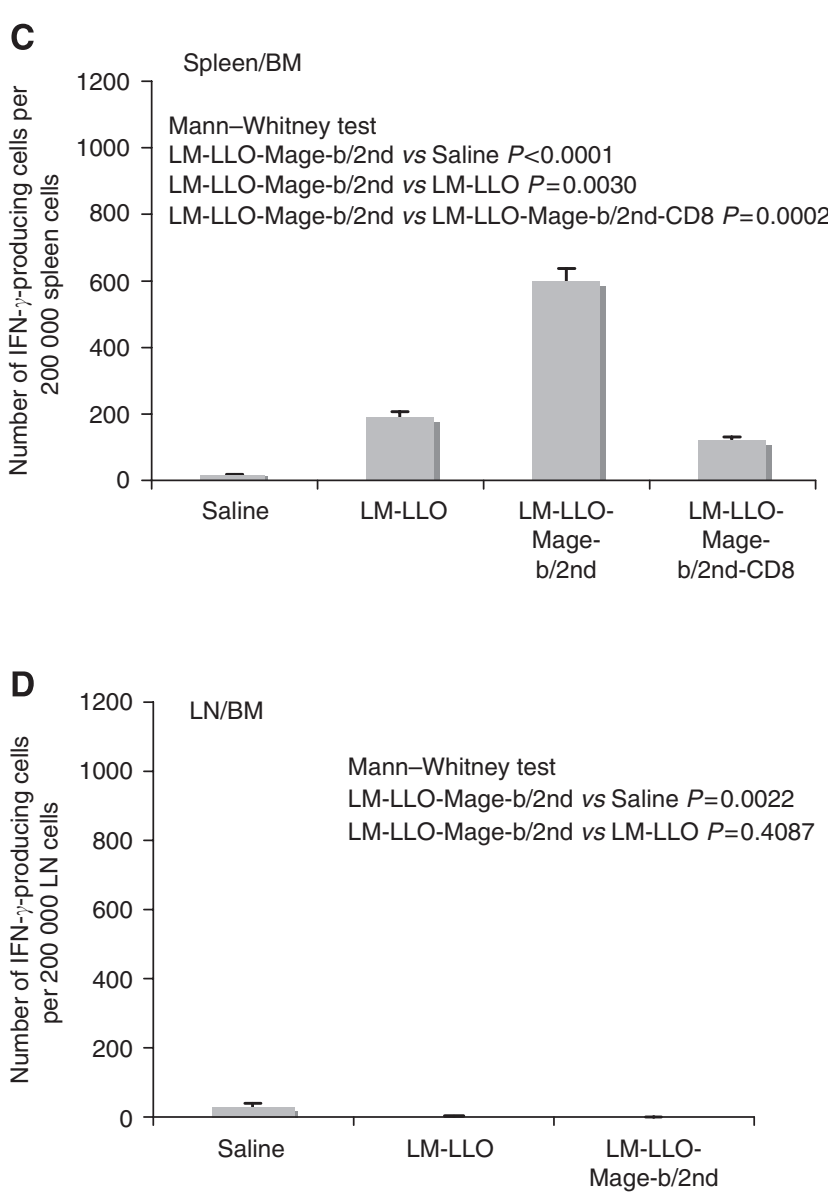

Figure 5 Mage-b-specific immune responses in vitro. BALB/c mice were immunised with the LM-LLO-Mage-b/2nd vaccine strain and challenged with 4TI tumour cells as outlined in Figure I, or not challenged with 4TI tumour cells. Two weeks after tumour challenge, mice were euthanized and spleens and draining (inguinal) lymph nodes (LNs) were analysed for in vitro immune responses upon restimulation with Mage-b. For this purpose, the number of IFN $\gamma$ producing cells in spleens of mice without $(\mathbf{A})$ and with $(\mathbf{B}) 4 \mathrm{TI}$ tumours and metastases were compared. Again, the number of IFN $\gamma$-producing cells were determined in spleens $(\mathbf{C})$ but now compared with the number of IFN $\gamma$-producing cells in the LNs $(\mathbf{D})$ of mice bearing $4 T$ I tumours and metastases were compared. Lymph nodes and spleens were from the same mice, and tested in the same experiment. In panel C, spleen cells depleted for CD8 T cells are shown as well. All restimulation assays were performed with bone marrow (BM) cells transfected with pCDNA3. I-Mage-b and pCMVI-GM-CSF plasmid DNA. Two days later, Mage-b-specific immune responses were analysed by ELISPOT. Controls such as BM cells transfected with pcDNA3.I-Mage-b, or with PCMV-GM-CSF, or non-transfected BM cells did not produce IFN (data not shown). The LM-LLO-Mage-b/2nd vaccine was tested in three independent experiments. Results were averaged and subjected to statistical analysis using Mann-Whitney test ( $n=5$ mice per group in each experiment). The error bars represent the s.e.m.

in the group of LM-LLO-Mage-b/2nd compared with the control groups (Figure 5B), demonstrating that LM-LLO-Mage-b/2nd was able to induce Mage-b-specific immune responses even in mice with 4T1 tumours. Finally, immune responses in the spleens were compared with immune responses in the draining LNs (at the site of the primary tumours), both isolated from the same mice with 4T1 tumours and metastases, and restimulated in the same experiment, as described above. While strong Mage-b-specific immune responses were observed in the spleen (Figure $5 \mathrm{C}$ ), those immune responses were completely absent in the draining LNs (Figure 5D). Depletion of CD8 T cells showed a decrease in the number of IFN $\gamma$-producing cells in the spleen by $80 \%$ (Figure $5 \mathrm{C}$ ). No significant increase was observed in the number of IL-2producing cells of the group of vaccinated mice compared with the control mice and therefore not shown.

\section{The effect of IL-6 on Mage-b-specific immune responses in vitro}

As shown in Figure 5C and D, Mage-b-specific CD8 T-cell responses were present in the spleen, but completely absent at the site of the primary tumours (in draining LN). This implies that at the site of the primary tumours, either Mage-b-specific CD8 T cells are absent, or that Mage-b-specific CD8 T cells are present but failed to function, for example, by the factor(s) produced by the primary tumours. We analysed this latter possibility. In previous studies, we found that $4 \mathrm{~T} 1$ primary tumours produced high levels of IL-6 (Gravekamp et al, 2008). Interleukin-6 is a potential candidate for T-cell inhibition. In the current study, the effect of anti-IL-6 antibodies as well as of purified IL- 6 on Mage-b-induced immune responses has been analysed in vitro. For this purpose, anti-IL-6 antibodies were added to LNs of $4 \mathrm{~T} 1$ tumour-bearing mice, restimulated with Mage- $b$. To avoid the generation of immune responses against all other TAA than Mage-b, we used $64 \mathrm{pT}$ instead $4 \mathrm{~T} 1$ tumour cells in the restimulation assay. $64 \mathrm{pT}$ is a syngeneic breast tumour cell, highly expressing Mage-b (Gravekamp et al, 2004) and highly secreting IL-6 (3000 $\mathrm{pg} \mathrm{ml}^{-1}$ ) (Gravekamp et al, 2008). Indeed, addition of anti-IL-6 antibodies to the in vitro restimulation assay significantly increased the production of IFN $\gamma$, whereas the production of IFN $\gamma$ could not be induced in the same restimulation assay without anti-IL-6 antibodies (Figure 6A). In accordance with this result, the addition of purified IL- 6 to spleen cells of $4 \mathrm{~T} 1$ tumour-bearing mice that were immunised with LM-LLO-Mage-b/2nd, completely inhibited 

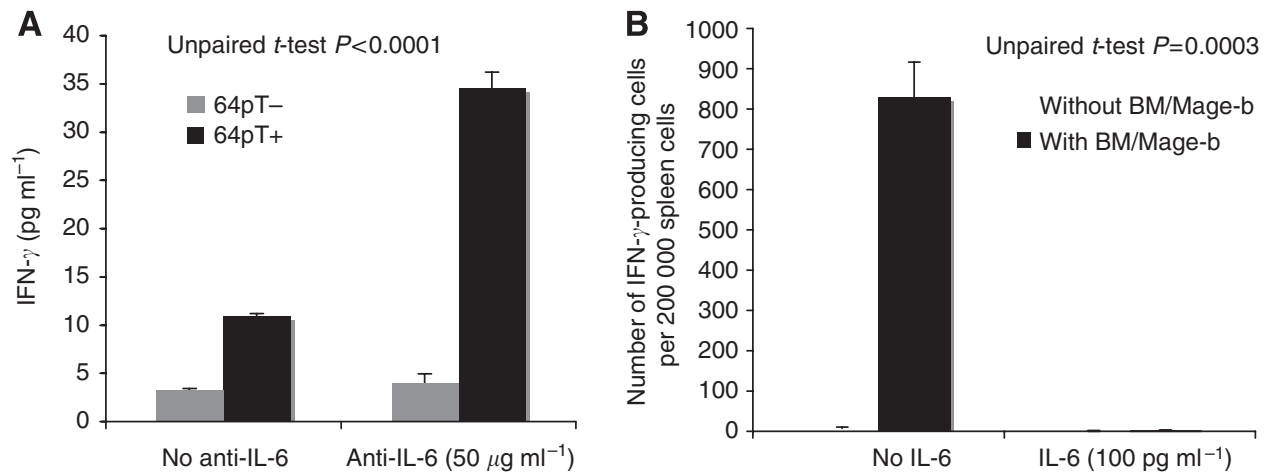

Figure 6 Effect of IL-6 on Mage-b-induced immune responses in vitro. To analyse the effect of IL-6 on Mage-b-specific immune responses in vitro, draining lymph nodes (LNs) of 4TI tumour-bearing mice were cocultured with or without 64pT tumour cells, expressing highly Mage-b, and producing high levels of IL-6. These cocultures were performed in the absence or presence of anti-IL-6 antibodies (A). After 2 days of stimulation, the production of IFN $\gamma$ was determined with quantitative ELISA. In this experiment, the lymph nodes (LNs) of I 0 mice were pooled. In addition, spleen cells of 4TI tumour-bearing mice were cocultured with or without autologous bone marrow (BM) cells transfected with pcDNA3.I-Mage-b and pCMV-GM-CSF. These cocultures were performed in the absence or presence of purified IL-6 (B). After 2 days of stimulation, the number of IFN $\gamma$-producing cells was determined with an ELISPOT reader. This experiment was performed twice with spleens of mice that received vaccination with LM-LLO-Mage-b/2nd. In each experiment, spleens of five mice were pooled. Controls such as BM cells transfected with pcDNA3.I-Mage-b and/or pCMV-GM-CSF, or non-transfected BM cells, did not produce IFN $\gamma$ (data not shown). The results of both assays were subjected to statistical analysis using the unpaired $t$-test. The error bars represent the s.e.m.

the generation of IFN $\gamma$-producing cells upon restimulation with $\mathrm{BM}$ cells highly expressing Mage-b, while in the absence of purified IL-6, a high number of IFN $\gamma$-producing cells was detected (Figure 6B).

\section{DISCUSSION}

Clinical trials have shown that vaccination with MAGE has effect on metastases (Thurner et al, 1999; Marchand et al, 2003; Kruit et al, 2005; Lurquin et al, 2005; Van Baren et al, 2005), but improvement of MAGE vaccines is strongly needed. In previous studies, we have shown that immunisation with Mage-b combined with GM-CSF plasmid DNA and thioglycollate reduced the number of metastases by $65 \%$ compared with the control group in a highly metastatic breast tumour model, 4T1 (Gravekamp et al, 2008). In this study, we have further improved Mage-b vaccination by using an improved delivery system, that is, recombinant LM. Listeria monocytogenes infects primarily APC such as macrophages and DCs, and delivers the Mage-b antigen with high efficiency to the APC. Three overlapping fragments of Mage-b (LM-LLO-Mage-b/ 1st, LM-LLO-Mage-b/2nd, and LM-LLO-Mage-b/3rd) as well as the complete protein-encoding region of Mage-b (LM-LLO-Mage-b/ complete) have been expressed in recombinant LM. Each fragment of Mage-b as well as the complete Mage-b is secreted as a fusion protein with a truncated, non-cytolytic form of LLO. Most effective was the LM-LLO-Mage-b/2nd vaccine strain. Vaccination with LMLLO-Mage-b/2nd dramatically reduced the number of metastases by $96 \%$ compared with the saline group and by $88 \%$ compared with the vector control group, and this correlated with strong Mage-b-specific CD8 T-cell responses in the spleen upon restimulation with Mage-b. These results suggest that LM-LLOMage-b/2nd (position 311-660 of the cDNA of Mage-b) may contain a higher number of, or more effective protective epitope(s) than LM-LLO-Mage-b/1st or LM-LLO-Mage-b/3rd. No further analysis has been performed in this study to identify protective epitope(s) within the Mage-b protein. We have studied Mage-bspecific CD8 T cells secreting IFN $\gamma$, as tumour cell kill is mediated through CD8 function (Singh et al, 2005). However, recent studies show that CD4 helper $\mathrm{T}$ cells, secreting IFN $\gamma$, may play an important role in tumour rejection as well (Qian et al, 2004; Chikamatsu et al, 2008).

The LM-LLO had an effect on the metastases, and it significantly reduced the number of metastases compared with the saline group.
Evidence exists that LM-LLO itself can activate CD8 T cells, as well as NK cells and NK DCs (NKDCs) to produce IFN $\gamma$ in vivo (Messingham et al, 2007; Plitas et al, 2007). Indeed, we found IFN $\gamma$ producing CD8 $\mathrm{T}$ cells, NK cells, and macrophages, in spleen cultures of mice immunised with LM-LLO or LM-LLO-Mage-b/ 2nd, restimulated with LM-LLO (data not shown). IFN $\gamma$ has an antimetastatic effect (Hayakawa et al, 2002), and may explain the effect of LM-LLO on the metastases.

Despite the dramatic effect on the metastases, no reduction in the growth of 4T1 primary tumours was observed in mice vaccinated with the LM-LLO-Mage-b/2nd or with the other Mage vaccine strains compared with the control groups. In correlation with this effect, we found that Mage-b-specific immune responses were completely absent in the LNs at the site of the primary tumours. However, both 4T1 tumours and metastases expressed high levels of Mage-b. This implies that Mage-b-specific CD8 T cells are either absent, or present but inhibited in function at the site of the primary tumours. In previous studies with pcDNA3.1Mage- $b$ vaccination, we found that the number of CD8 $\mathrm{T}$ cells significantly increased in the $4 \mathrm{~T} 1$ tumours of Mage-b vaccinated mice compared with the control groups, despite very poor Mage-bspecific immune responses (IFN $\gamma$ production) in the draining LNs (Gravekamp et al, 2008). With this in mind, the inhibition of T-cell function may be more likely than the absence of Mage-b-specific CD8 T cells at the site of the primary tumours. Many tumours produce and accumulate lymphokines or factors at high levels that may inhibit vaccine-induced T-cell responses such as IL-6, transforming growth factor (TGF $\beta)$, IL-10, cyclooxygenase (COX)-2, and its product prostaglandine E, PD1-ligand or indolamine, 2,3-dioxygenase (IDO; Gajewski et al, 2006). In a previous study, we found that IL- 6 and TGF $\beta$ are highly produced by the 4T1 primary tumours and metastases (Gravekamp et al, 2008). Evidence exists that $\operatorname{TGF} \beta$ may induce regulatory $\mathrm{T}$ cells $\left(\mathrm{T}_{\text {regs }}\right)$ (DiPaolo et al, 2007) at the site of the primary tumour. Indeed, very recently, it has been reported that $4 \mathrm{~T} 1$ tumours are massively infiltrated with $\mathrm{T}_{\text {regs }}$ preventing efficient activation of CD8 T cells (Chaput et al, 2007). In humans also $\mathrm{T}_{\text {regs }}$ cells have been found at the site of the primary tumours, including breast cancer (Liyanage et al, 2002).

In addition to TGF $\beta$, we found suggestive evidence that IL- 6 may have contributed to T-cell unresponsiveness as well. Interleukin-6 is a potent regulator of DC differentiation (Park et al, 2004), and is able to initiate the expression of STAT3 in DC. High levels of STAT3 can prevent the maturation of DC and subsequent 
presentation of antigens (Xie et al, 2003), resulting in T-cell inhibition. Both 4T1 primary tumours and metastases secrete IL-6 (Gravekamp et al, 2008). However, the primary tumours are $100-$ 100000 times larger than the metastases. Therefore, it is expected that the accumulation of IL- 6 is much higher in the environment of the primary tumours than in the environment of the metastases. We then hypothesised that the high accumulation of IL- 6 may have downregulated Mage-b-specific immune responses at the site of the primary tumour. To evaluate this hypothesis, we analysed the effect of IL-6 on Mage-b-specific immune responses in vitro. Indeed, IL-6-neutralising antibodies were able to restore Mage-bspecific immune responses in draining LNs of $4 \mathrm{~T} 1$ tumour-bearing mice in vitro when restimulated with Mage-b, whereas purified IL6 completely prevented the induction of Mage-b-specific immune responses in the spleen of $4 \mathrm{~T} 1$ tumour-bearing mice, when restimulated with Mage-b. Here, we demonstrated that IL-6 contributed to the inhibition of Mage-b-specific immune responses in vitro. Whether IL-6 has contributed to T-cell inhibition at the site of the primary tumour in vivo needs to be further analysed. High levels of IL- 6 have been found in many human breast cancers (Kuang et al, 1998; Sotiriou et al, 2001). Moreover, IL-6 promotes tumour growth (Celis et al, 2005) and may induce chemoresistance (Conze et al, 2001). Therefore, agents that inhibit the production of IL- 6 could improve the efficacy of vaccination or chemotherapy against breast cancer.

Finally, we have studied safety issues of the LM-LLO-Mage-b/ 2nd vaccine. It is known that LM infects kupfer cells and hepatocytes in the liver, macrophages in the spleen, and epithelial cells in the gastro intestines (GI) (Vazquez-Boland et al, 2001). However, the attenuated Listeria bacteria will be cleared by the immune system within 3-5 days after immunisation. After three immunisations with LM-LLO-Mage-b/2nd, we found some inflammatory spots in the liver, but not in the spleen or GI. Moreover, LM-LLO-based vaccines have been already tested in cancer patients in phase I/II clinical trials, and flu-like symptoms are the only side effects observed (Rothman, 2008).

In summary, we have demonstrated here that vaccination with LM-LLO-Mage-b/2nd reduced the number of $4 \mathrm{~T} 1$ metastases dramatically in correlation with robust Mage-b-specific CD8 T-cell responses in vitro. Unfortunately, no effect was observed on the primary tumours, and this was correlated with the complete absence of Mage-b-specific T-cell responses in vitro. Therefore, our results suggest that vaccination with MAGE-B/2nd may dramatically improve the clinical outcome of breast cancer therapy, if applied after removal of the primary tumour.

\section{ACKNOWLEDGEMENTS}

We thank Dr ZhenHang Meng for the pathological analysis of the mouse tissues, and Sue Louiseau for editing the manuscript. This work was supported by NIA Grant 1RO1 AG023096-01 and the American Federation for Aging Research (AFAR) A000106.

\section{REFERENCES}

Alberg AJ, Singh S (2001) Epidemiology of breast cancer in older women: implications for future health care. Drugs Aging 18: $761-762$

Althuis MD, Dozier JM, Anderson WF, Devesa SS, Brinton LA (2005) Global trends in breast cancer incidence and mortality 1973-1997. Int J Epidemiol 34: 405-412

Aslakson CJ, Miller FR (1992) Selective events in the metastatic process defined by analysis of the sequential dissemination of subpopulations of a mouse mammary tumor. Cancer Res 152: 1399

Berkowitz N, Gupta S, Silberman G (2000) Estimates of the lifetime direct costs of treatment for metastatic breast cancer. Value Health 3: 23-30

Celis JE, Moreira JMA, Cabezon T, Gromov P, Friis E, Rank F, Gromova I (2005) Identification of extracellular and intracellular signaling components of the mammary adipose tissue and its interstitial fluid in high risk breast cancer patients. Mol Cell Proteomics 4: 492-522

Chambers RS, Johnston SA (2003) High-level generation of polyclonal antibodies by genetic immunization. Nature Biotechnol 21: 1088-1092

Chaput N, Darasse-Jeze G, Bergot AS, Cordier C, Ngo-Abdalla S, Klatzmann D, Azogui O (2007) Regulatory T cells prevent CD8 T cell maturation by inhibiting CD4 Th cells at tumor sites. J Immunol 179: 4969-4978

Chikamatsu K, Sakakura K, Yamamoto T, Furaya N, Whiteside TL, Masuyama K (2008) CD4+ $\mathrm{T}$ helper responses insquamous cell carcinoma of the head and neck. Oral Oncol DOI:10.1016/j.oraloncology.2007.11.001

Conze D, Weiss L, Regen PS, Bhushan A, Weaver D, Johnson P, Rincón M (2001) Autocrine production of interleukin-6 causes multidrug resistance in breast cancer cells. Cancer Res 61: 8851-8858

De Backer O, Verheyden AM, Martin B, Godelaine D, De Plaen E, Brasseur R, Avner P, Boon T (1995) Structure, chromosomal location, and expression pattern of three mouse genes homologous to the human MAGE genes. Genomics 28: $74-83$

De Plaen E, De Backer O, Arnaud D, Bonjean B, Chomez P, Martelange V, Avner P, Baldacci P, Babinet C, Hwang SY, Knowles B, Boon T (1999) A new family of mouse genes homologous to the human MAGE genes. Genomics 55: $176-184$

DiPaolo RJ, Brinster C, Davidson TS, Andersson J, Glass D, Shevach EM (2007) Autoantigen-specific TGF $\beta$-induced Foxp3+ regulatory $\mathrm{T}$ cells prevent autoimmunity by inhibiting dendritic cells from activating autoreactive T cells. J Immunol 179: 4685-4693
Gajewski TF, Meng Y, Harlin H (2006) Immune suppression in tumor microenvironment. J Immunother 29: 233-240

Gravekamp C (2007) Cancer vaccines in old age. Exp Ger 42: $441-450$

Gravekamp C, Leal B, Denny A, Bahar R, Lampkin S, Castro F, Kim SH, Moore D, Reddick $\mathrm{R}$ (2008) In vivo responses to vaccination with Mage-b, GM-CSF and thioglycollate in a highly metastatic mouse breast tumor model, 4T1. Cancer Immunol Immunother 57: 1067-1077

Gravekamp C, Sypniewska R, Gauntt S, Tarango M, Price P, Reddick R (2004) Behavior of metastastic and non-metastatic breast tumors in old mice. EBM 229: $665-675$

Gunn GR, Zubair A, Peters C, Pan ZK, Wu TC, Paterson Y (2001) Two Listeria monocytogenes vaccine vectors that express different molecular forms of human papilloma virus-16 (HPV-16) E7 induce qualitatively different $\mathrm{T}$-cell immunity that correlates with their ability to induce regression of established tumors immortalized by HPV-16. J Immunol 167: $6471-6479$

Hayakawa Y, Takeda K, Yagita H, Smyth MJ, Van Kaer L, Okumura K, Saiki I (2002) IFN $\gamma$-mediated inhibition of tumor angiogenesis by natural killer T-cell ligand, $\alpha$-galactosylceramide. Immunobiology 100: 1728-1733

Hsieh CS, Macatonia SE, Tripp CS, Wolf SF, O’Garra A, Murphy KM (1993) Development of Th1 CD4+ T cells through IL-12 produced by Listeria-induced macrophages. Science 260: $547-549$

Kruit WH, van Ojik HH, Brichard VG, Escudier B, Dorval T, Dréno B, Patel P, van Baren N, Avril MF, Piperno S, Khammari A, Stas M, Ritter G, Lethé B, Godelaine D, Brasseur F, Zhang Y, van der Bruggen P, Boon T, Eggermont AM, Marchand M (2005) Phase $\frac{1}{2}$ study of subcutaneous and intradermal immunization with a recombinant MAGE-3 protein in patients with detectable metastatic melanoma. Int J Cancer 117: 596-604

Kuang Y, Zhang Z, Zhang X (1998) Interleukin-6 and its soluble receptors in human breast cancer. Zhonghua Zhong Liu Za Zhi 20: 305-357

Kurtz JE, Dufour P (2002) Strategies for improving quality of life in older patients with metastatic breast cancer. Drugs Aging 19: 605-622

Lelekakis M, Moseley JM, Martin TJ, Hards D, Williams E, Ho P, Lowen D, Javni J, Miller FR, Slavin J, Anderson RL (1999) A novel orthotopic model of breast cancer metastasis to bone. Clin Exp Metastasis 17: $163-170$

Liyanage UK, Moore TT, Joo HG, Tanaka Y, Herrman V, Doherty G, Drebin JA, Strasberg SM, Eberlein TJ, Goedegebuure PS, Linehan DC (2002) 
Prevalence of regulatory $\mathrm{T}$ cells is increased in peripheral blood and tumor microenvironment in patients with pancreas or breast adenocarcinoma. J Immunol 169: 2756-2761

Lurquin C, Lethe B, De Plaen E, Corbiere PG, Boon T (2005) Contrasting frequencies of antitumor and anti-vaccine $\mathrm{T}$ cells in metastases of a melanoma patient vaccinated with a MAGE tumor antigen. JEM 201: 249-257

Marchand M, Punt CJ, Aamdal S, Escudier B, Kruit WH, Keilholz U, Håkansson L, van Baren N, Humblet Y, Mulders P, Avril MF, Eggermont AM, Scheibenbogen C, Uiters J, Wanders J, Delire M, Boon T, Stoter G (2003) Immunization of metastatic cancer patients with MAGE-3 protein combined with adjuvant SBAS-2: a clinical report. Eur J Cancer 39: $70-77$

Messingham KAN, Badovinac VP, Jabbari A, Harty JT (2007) A role for IFN $\gamma$ antigen-specific CD8+ T cells in protective immunity to Listeria monocytogenes. J Immunol 179: 2457-2466

Pardal R, Clarke MF, Morrison SJ (2003) Applying the principles of stem-cell biology to cancer. Nat Rev Cancer 3: 895-902

Pan ZK, Weiskirch LM, Paterson Y (1999) Regression of established B16F10 melanoma with recombinant Listeria monocytogenes vaccine. Cancer Res 59: $5264-5269$

Park JW, Kwon TK, Kim IH, Sohn SS, Kim YS, Kim CI, Bae OS, Lee KS, Lee KD, Lee CS, Chang HK, Choe BK, Ahn SY, Jeon CH (2002) A new strategy for the diagnosis of MAGE-expressing cancers. J Immunol 79: 79-86

Park SJ, Nakgawa T, Kitamura H, Atsumi T, Kamon H, Sawa S, Kamimura D, Ueda N, Iwakura Y, Ishihara K, Murakami M, Hirano T (2004) IL-6 regulates in vivo dendritic cell differentiation through STAT3 activation. J Immunol 173: $3844-3854$

Paterson Y, Maciag PC (2005) Listeria-based vaccines for cancer treatment. Curr Opin Mol Ther 7: 454-460

Plitas G, Chaudry UI, Kingham TP, Raab JR, DeMatteo RP (2007) NK dendritic cells are innate immune responders to Listeria monocytogenes infection. J Immunol 178: $4411-4416$

Qian F, Gnjatic S, Jager E, Santiago D, Jungbluth A, Grande C, Schneider S, Keitz B, Driscoll D, Ritter G, Lele S, Sood A, Old LJ, Odunsi K (2004) Th1/ Th2 CD4+ T cell responses against NY-ESO-1 in HLA-DPB1*0401/0402 patients with epithelial ovarian cancer. Cancer Immun 4: 12-20

Rak JW, McEachern D, Miller FR (1992) Sequential alteration of peanut agglutinin binding-glycoprotein expression during progression in murine mammary neoplasia. Br J Cancer 65: 641-648

Reeves FR, Reeves PA (2003) Current protocols in immunology. In Care and Handling of Laboratory Animals, Coligan JE, Kruisbeek AM, Bierer BE, Margulies DH, Shevach EM, Strober W (eds), Vol. 1, City of University of New York Medical School, John and Wiley and Sons Inc, Food and Drug Administration: Bethesda, Maryland. P1.9.1-1.9.3
Rothman J (2008) The First Use of a Live Listeria Cancer Vaccine in Man. AACR Conference: San Diego, CA. $12-16$ April 2008. Abstract 225

Scart H, Cantin J, Levin M (2002) Clinical practice guidelines for the care and treatment of breast cancer: Mastectomy or lumpectomy? The choice of operation for clinical stages I and II breast cancer (summary of the 2002 update). CMAJ 167: 145-155

Singh R, Domineicki ME, Jaffee EM, Paterson Y (2005) Fusion of Listeriolysin $\mathrm{O}$ and delivery by Listeria monocytogenes enhances the immunogenicity of HER-2/neu and reveals subdominant epitopes in the FVB/N mouse. J Immunol 175: 3663-3673

Sotiriou C, Lacroix M, Lespagnard L, Larsimont D, Paesmans M, Body JJ (2001) Interleukins-6 and -11 expression in primary breast cancer and subsequent development of bone metastases. Cancer Lett 169: 87-95

Sypniewska RK, Hoflack L, Tarango M, Gauntt S, Leal BZ, Reddick RL, Gravekamp C (2005) Prevention of metastases with a Mage-b DNA vaccine in a mouse breast tumor model: potential for breast cancer therapy. BCRT 91: 19-28

Thurner B, Haendle I, Roder C, Dieckmann D, Keikavoussi P, Jonuleit H, Bender A, Maczek C, Schreiner D, von den Driesch P, Bröcker EB, Steinman RM, Enk A, Kämpgen E, Schuler G (1999) Vaccination with Mage-3A1 peptide-pulsed mature monocyte-derived dendritic cells expands specific cytotoxic $\mathrm{T}$ cells and induces regression of some metastases in advanced Stage IV melanoma. JEM 190: 1669-1678

Van Baren N, Bonnet MC, Dreno B, Khammari A, Dorval T, Piperno-Neumann S, Liénard D, Speiser D, Marchand M, Brichard VG, Escudier B, Négrier S, Dietrich PY, Maraninchi D, Osanto S, Meyer RG, Ritter G, Moingeon P, Tartaglia J, van der Bruggen P, Coulie PG, Boon T (2005) Tumoral and immunological response after vaccination of melanoma patients with ALVAC virus encoding MAGE antigens recognized by T cells. J Clin Oncol 23: $9008-9021$

Vazquez-Boland JA, Kuhn M, Berche P, Chakraborty T, Dominguez-Bernal G, Goebel W, Gonzalez-Zorn B, Wehland J, Kreft J (2001) Listeria Pathogenesis and molecular virulence determinants. Clin Microbiol Rev 14: $584-640$

Xie J, Qian J, Wang S, Freeman III ME, Epstein J, Yi Q (2003) Novel and detrimental effects of lipopolysccharide on in vitro generation of immature dendritic cells: Involvement of mitogen-activated protein kinase p38. J Immunol 171: $4792-4800$

Yang B, O'Herrin SM, Wu J, Reagan-Shaw S, Ma Y, Bhat KM, Gravekamp C, Setaluri V, Peters N, Hoffmann FM, Peng H, Ivanov AV, Simpson AJ, Longley BJ (2007) MAGE-A, mMage-b, and MAGE-C proteins form complexes with KAP1 and suppress p53-dependent apoptosis in MAGEpositive cell lines. Cancer Res 67: 9954-9962 